Article

\title{
Performance of Pinoxaden on the Control of Diclofop-Resistant Italian Ryegrass (Lolium perenne L. ssp. multiflorum) in Winter Wheat
}

\author{
Taghi Bararpour ${ }^{1, *}$, Nicholas E. Korres ${ }^{2}$, Nilda R. Burgos ${ }^{2}{ }^{\circledR}$, Ralph R. Hale ${ }^{1}$ and \\ Te-Ming P. Tseng ${ }^{3}$ \\ 1 Delta Research and Extension Center, Mississippi State University, 82 Stoneville Rd., Stoneville, MS 38776, \\ USA; rrh187@msstate.edu \\ 2 Department of Crop, Soil and Environmental Sciences, University of Arkansas, 1366 W. Altheimer Dr., \\ Fayetteville, AR 72704, USA; nkorres@yahoo.co.uk (N.E.K.); nburgos@uark.edu (N.R.B.) \\ 3 Department of Plant and Soil Sciences, Mississippi State University, Mailstop 9555 Dorman Hall Mississippi \\ State, Starkville, MS 39762, USA; tt1024@msstate.edu \\ * Correspondence: mtb436@msstate.edu; Tel.: +1-662-686-9311
}

Received: 1 June 2018; Accepted: 6 July 2018; Published: 10 July 2018

\begin{abstract}
Resistance to herbicides in Italian ryegrass (Lolium perenne L. ssp. multiflorum (Lam.) Husnot) is an economically important herbicide-resistance issue in world agriculture. Diclofop-resistant ryegrass is the number one weed problem in Arkansas wheat. Field studies were conducted from 2006 through 2008 at Bredlow corner and Fayetteville, Arkansas, USA to determine the effect of herbicide programs consisting of pinoxaden (Axial) alone or in mixtures with preemergence and postemergence herbicides, along with tillage systems, for managing diclofop-resistant Italian ryegrass. Italian ryegrass control, wheat injury, and grain yield were evaluated. A single treatment with pinoxaden alone resulted in $58 \%$ ryegrass control and $1488 \mathrm{~kg} \mathrm{ha}^{-1}$ grain yield. The best treatment was metribuzin followed by mesosulfuron, which resulted in $2793 \mathrm{~kg}$ grain yield ha ${ }^{-1}$, a $47 \%$ increase compared to pinoxaden alone. In Fayetteville (2006-2007 and 2007-2008), the best treatment was two applications of metribuzin, which yielded about $3700 \mathrm{~kg}$ grain ha $\mathrm{ha}^{-1}$. A single application of pinoxaden resulted in $40 \%$ loss of grain yield compared to a single application of flufenacet + metribuzin and almost $50 \%$ yield loss compared to sequential application of metribuzin. Yield loss was attributed due to insufficient control of Italian ryegrass. The effect of tillage on Italian ryegrass was inconsistent between years and treatments. In the first year, for example, tillage $\times$ herbicide treatments did not differ. In the second and third year, control of Italian ryegrass was better in no-till than in conventional till in both locations. In conclusion, pinoxaden alone could not control diclofop-resistant Italian ryegrass sufficiently. Other herbicide modes of action need to be added to the management program of diclofop-resistant Italian ryegrass, especially one with residual activity such as metribuzin.
\end{abstract}

Keywords: ACCase inhibitor herbicide; cultural practices; graminicide herbicides; tillage; yield reduction

\section{Introduction}

Italian ryegrass (Lolium perenne L. ssp. multiflorum (Lam.) Husnot), a winter annual, is a problematic weed in small grains crops [1-3]. Reductions up to $61 \%$ in wheat grain yield were reported in the presence of Italian ryegrass $\left(93\right.$ plants $\mathrm{m}^{-2}$ ) which caused reductions in wheat tillering capacity and promoted lodging [4]. In a six-year study, Bararpour and Oliver [5] reported a natural population of diclofop-resistant Italian ryegrass that caused $72 \%$ wheat yields reduction. Conventional 
and organic wheat production systems are affected by infestations of Italian ryegrass and with the increase in resistance to herbicide modes of action and increased market for organic grain, alternative methods of control should be evaluated [3]. Bararpour et al. [6] reported Italian ryegrass in Arkansas capable of producing 45,000 seed plant ${ }^{-1}$.

Historically, diclofop, an Acetyl CoA carboxylase (ACCase)-inhibiting herbicide, has been used for the control of Italian ryegrass [7,8]. Diclofop applied POST at 500 to $1500 \mathrm{~g}$ ai/ha controlled Italian ryegrass $81 \%$ to $100 \%$, and increased wheat grain yield $20 \%$ to $60 \%$ [9-11]. Italian ryegrass is very competitive and has become progressively resistant to diclofop [12-14]. To mitigate this problem, producers have used acelactate synthase (ALS) inhibitors (mesosulfuron, pyroxsulam) POST, a photosynthesis inhibitor (metribuzin) PRE, glyphosate preplant, and other herbicides. As evolution by selection dictates, Italian ryegrass has also evolved tesistance to alternative herbicides. Perez and Kogan [15] reported a two- to four-fold resistance to glyphosate [15]. In 2003, a five-fold level of resistance to glyphosate was documented in Italian ryegrass in a filbert (Corylus avellana L.) orchard in Oregon [16,17]. In the United States, Nandula et al. [18] documented the first glyphosate-resistant (GR) Italian ryegrass in row crop production [17]. Thirty-two counties in Mississippi, and at least one county or parish in Arkansas, California, Louisiana, North Carolina, and Tennessee have GR Italian ryegrass populations $[17,19,20]$.

Italian ryegrass resistance to ALS inhibitors is becoming widespread in the southern USA. In Mississippi, two sulfometuron-resistant populations of Italian ryegrass were documented by Taylor and Coats [21]. Resistance to mesosulfuron was detected just after one year of commercial use in Arkansas, presumably due to preselection with other ALS herbicides [22]. Italian ryegrass populations have been confirmed resistant to acetolactate synthase-inhibiting herbicides in Arkansas, California, Delaware, Georgia, Idaho, Kentucky, Missouri, North Carolina, and South Carolina [20].

Due to the increasing evolution of herbicide-resistant Italian ryegrass, producers have adopted GR crop technologies to reduce input costs, equipment use, soil erosion, and number of herbicide applications and replaced conventional tillage practices with zero tillage or conservation tillage $[17,21,23,24]$. Conservation tillage promotes accumulation of plant residue at the soil surface that contributes to the inhibition of weed seed germination due to shading or cooler temperatures at the soil surface. It also increases the availability of soil nutrients (from enhanced microbial activities) and water by making the soil less vulnerable to erosion or evaporation processes [25]. In zero-till and low-input systems, Vencill and Banks [26] documented a rapid increase in soil seedbank due to inconsistent weed control [24]. Reduced tillage system favors Italian ryegrass proliferation, causing increased herbicide usage [27] and leading to selection of resistant biotypes. Like Italian ryegrass, the seedbank of common ragweed (Ambrosia artemisifolia L.), common lambsquarters (Chenopodium album L.), horseweed (Conyza Canadensis (L.) Cronq), and sicklepod (Senna obtusifolia (L.) Irwin and Barneby) also increased in reduced tillage systems [26,28]. Increasing tillage and subsequent cultivation disrupts the soil and can stimulate or reduce the germination of certain weed seeds [26]. Also, tillage timing can be a factor in reduction of weed seed viability, moving seeds to different depths in the soil profile and creating an unfavorable environment during critical stages of reproduction [28]. Integrating herbicide programs within a tillage system improves overall long-term weed control and increases crop production.

Pinoxaden [29] (Axial ${ }^{\circledR}$ XL herbicide, Syngenta Crop Protection, LLC, Greensboro, NC, USA) is an ACCase-inhibiting herbicide labeled for POST control of grass weed species in wheat and barley [28]. It is a welcome addition to the limited options for grass control in wheat. Unlike diclofop and other ACCase-inhibitor herbicides, pinoxaden is not antagonized by broadleaf herbicides and has a wider window of application in wheat. With the rapid adoption of pinoxaden, and subsequent monitoring of ryegrass populations, we learned that $25 \%$ of Italian ryegrass populations are cross-resistant to diclofop and pinoxaden [29].

Preserving technologies and herbicide regimes are important for the future of agriculture. Developing programs that integrate tillage and herbicide technology, with correct identification of 
weed species and understanding the biology of weed species are critical in increasing crop production to obtain maximum yield. Tillage and no-tillage systems can promote beneficial soil properties, but the type of system used for weed control can vary depending upon weed species. The objective of this research is to evaluate the integration of tillage into herbicide programs containing pinoxaden and other wheat herbicides for diclofop-resistant Italian ryegrass control and its effect on ryegrass soil seedbank.

\section{Materials and Methods}

\subsection{Site Description and Crop Establishment}

Two field experiments at two locations in Arkansas were conducted to investigate the efficacy of various herbicide combinations on diclofop-resistant Italian ryegrass. A tillage or no-tillage cropping system was included as an additional treatment in the second experiment. The first experiment was set up at the Agricultural Research Center, Fayetteville, Arkansas $\left(36.09507^{\circ} \mathrm{N}, 94.17547^{\circ} \mathrm{W}\right)$ on Albaquults silt-loam soil (21\% sand, $70 \%$ silt, $9 \%$ clay) with a pH of $5.8 \%$ and 0.5 organic matter content during 2005-2006 and 2007-2008. The second experiment was set up at Bredlow Corner $\left(34.5343^{\circ} \mathrm{N}\right.$, $\left.92.1013^{\circ} \mathrm{W}\right)$, Arkansas on a Yorktown silty clay ( $0 \%$ sand, $44 \%$ silt, $56 \%$ clay) soil with a $\mathrm{pH}$ of 5.8 , and $1.8 \%$ organic matter content during 2006-2009. In the fall vegetation in all plots were mowed and two weeks later, the conventional plots were tilled to prepare the seedbed for planting wheat.

Glyphosate was broadcasted to the entire experimental area immediately after planting to burndown undesirable vegetation. Winter wheat 'Beretta 989' (@2011 AgriPro, Syngenta. Jasper, $\mathrm{MO}$, USA) was planted at $112 \mathrm{~kg} \mathrm{ha}^{-1}$ seed in a $10 \times 10 \mathrm{~m}$ experimental plot with row spacing at 18 $\mathrm{cm}$ in both locations. Wheat emerged approximately 10-14 days after planting (DAP); the desired crop stand was attained. Details of planting dates and crop emergence are shown in Table 1.

Table 1. Winter wheat planting, emergence and harvesting dates for both Fayetteville and Bredlow Corner field experiments.

\begin{tabular}{ccccc}
\hline Location & Year & Planting Date & Crop Emergence & Harvest \\
\hline \multirow{2}{*}{ Fayetteville } & $2006-2007$ & 10 October 2006 & 26 October 2006 & 22 May 2007 \\
& $2007-2008$ & 15 October 2007 & 27 October 2007 & 19 May 2008 \\
\hline \multirow{3}{*}{ Bredlow corner } & $2006-2007$ & 6 October 2006 & 21 October 2006 & 13 June 2007 \\
& $2007-2008$ & 6 November 2007 & 16 November 2007 & 3 July 2008 \\
& $2008-2009$ & 10 October 2008 & 26 October 2008 & 16 June 2009 \\
\hline
\end{tabular}

\subsection{Ryegrass Population and Herbicide Treatments}

The experimental site had a uniform distribution of naturally occurring diclofop-resistant Italian ryegrass in both locations. The density of Italian ryegrass was estimated using a $0.5 \mathrm{~m} \times 0.5 \mathrm{~m}$ quadrat at two randomly selected sampling points within each plot and was found to be $323 \pm 12$ and $600 \pm 10$ plants $\mathrm{m}^{-2}$ at Fayetteville and Bredlow Corner, respectively.

A complete randomized block design with four replications was adopted for the first experiment at Fayetteville. The second experiment was established as a split-split plot design with three replications; whole-plot being the tillage regime (tilled vs. no-tilled) and sub-plot being herbicide treatment (Tables 2 and 3).

A $\mathrm{CO}_{2}$-pressurized backpack sprayer with four 8002 flat-fan nozzles (TeeJet Technologies, Springfield, IL, USA) handheld boom calibrated to deliver $187 \mathrm{~L} \mathrm{ha}^{-1}$ at $276 \mathrm{kPa}$ was used. 
Table 2. Herbicide treatments for the control of diclofop-resistant Italian ryegrass in the first field experiment at Fayetteville, Arkansas.

\begin{tabular}{|c|c|c|c|c|c|c|c|}
\hline $\begin{array}{l}\text { Treatment } \\
\text { ID }\end{array}$ & $\begin{array}{l}\text { Herbicide } \\
\text { Treatment }\end{array}$ & $\begin{array}{c}\text { Application } \\
\text { Rate }\end{array}$ & $\begin{array}{c}\text { Growth } \\
\text { Stage * at } \\
\text { Application }\end{array}$ & Wheat & Ryegrass & $\begin{array}{l}\text { Trade } \\
\text { Name }\end{array}$ & Manufacturer \\
\hline \multicolumn{8}{|c|}{$\mathrm{kg}$ ai ha ${ }^{-1}$} \\
\hline 1 & Pinoxaden $^{+}$ & 0.060 & $21-22$ & & $x$ & Axial & Syngenta \\
\hline 2 & $\begin{array}{l}\text { Flufenacet fb } \\
\text { Metribuzin }\end{array}$ & 0.476 & $12-13$ & $x$ & & Axiom & $\begin{array}{c}\text { Bayer } \\
\text { CropScience }\end{array}$ \\
\hline \multirow[t]{2}{*}{3} & Metribuzin $\mathrm{fb}$ & 0.280 & $12-13$ & $x$ & & Sencor & \multirow{2}{*}{$\begin{array}{c}\text { Bayer } \\
\text { CropScience }\end{array}$} \\
\hline & Metribuzin & 0.280 & $22-23$ & $x$ & & Sencor & \\
\hline
\end{tabular}

${ }^{*}$ Refers to Zadoks et al. [30] growth scale for cereals and grasses; ${ }^{\dagger}$ adjuvant (Adigor) at $0.375 \% v / v . \times$ denotes application of herbicides used; $\mathrm{fb}=$ followed by.

Table 3. Herbicide treatments for the control of diclofop-resistant Italian ryegrass in the second field experiment at Bredlow Corner, Arkansas.

\begin{tabular}{|c|c|c|c|c|c|c|c|}
\hline $\begin{array}{l}\text { Treatment } \\
\text { ID }\end{array}$ & $\begin{array}{l}\text { Herbicide } \\
\text { Treatment }\end{array}$ & $\begin{array}{l}\text { Application } \\
\text { Rate }\end{array}$ & $\begin{array}{c}\text { Growth } \\
\text { Stage *at } \\
\text { Application }\end{array}$ & Wheat & Ryegrass & $\begin{array}{l}\text { Trade } \\
\text { Name }\end{array}$ & Manufacturer \\
\hline \multicolumn{8}{|c|}{$\mathrm{kg}_{\mathrm{ai}} \mathrm{ha}^{-1}$} \\
\hline 1 & Pinoxaden $^{+}$ & 0.060 & $21-22$ & \multirow{5}{*}{$\times$} & $x$ & Axial & Syngenta \\
\hline 2 & Metribuzin fb & 0.280 & $12-13$ & & & Sencor & $\begin{array}{c}\text { Bayer } \\
\text { CropSience }\end{array}$ \\
\hline \multirow{3}{*}{3} & Pinoxaden $\ddagger$ & 0.060 & $21-22$ & & $x$ & Axial & Syngenta \\
\hline & $\begin{array}{l}\text { Mesosulfuron } \\
\quad \ddagger \mathrm{fb}\end{array}$ & 0.069 & $21-22$ & & $\times$ & Osprey & $\begin{array}{c}\text { Bayer } \\
\text { CropScience }\end{array}$ \\
\hline & $\underset{\ddagger}{\text { Mesosulfuron }}$ & 0.069 & $14-22$ & & $\times$ & Osprey & $\begin{array}{c}\text { Bayer } \\
\text { CropScience }\end{array}$ \\
\hline 4 & $\underset{\ddagger}{\text { Mesosulfuron }}$ & 0.015 & $21-22$ & \multirow{3}{*}{$\times$} & $\times$ & Osprey & $\begin{array}{c}\text { Bayer } \\
\text { CropScience }\end{array}$ \\
\hline \multirow[t]{2}{*}{5} & Metribuzin fb & 0.280 & $12-13$ & & & Sencor & $\begin{array}{c}\text { Bayer } \\
\text { CropScience }\end{array}$ \\
\hline & $\underset{\ddagger}{\text { Mesosulfuron }}$ & 0.0134 & $21-22$ & & $\times$ & Osprey & $\begin{array}{c}\text { Bayer } \\
\text { CropScience }\end{array}$ \\
\hline
\end{tabular}

${ }^{*}$ Refers to Zadoks et al. [30] growth stage scale for cereals and grasses; ${ }^{\dagger}$ adjuvant (Adigor) at $0.375 \% v / v ;{ }^{\ddagger}$ MSO (destiny) at $1 \% v / v ; \times$ denotes application of herbicides used; $\mathrm{fb}=$ followed by.

\subsection{Data Collection and Statistical Analysis}

Crop injury and weed control were scored on a scale of 0-100 ( 0 being no injury or weed control and 100 being complete crop death or weed control) on a weekly basis starting 8 weeks after crop emergence (WAE). All data were analyzed with JMP Pro 13.1 (SAS Institute Inc., Cary, NC, USA). For data that met the assumptions for ANOVA, means were separated using Fisher's protected Least Significant Difference (LSD) $(\alpha=0.05)$. Because of environmental and climatic differences between years, data were analyzed for each individual year. The effect of tillage on Italian ryegrass control was inconsistent through years; therefore, data were analyzed separately by year. The effect of year or tillage on grain yield, adjusted at $13 \%$ moisture content, was not significant; hence, data were combined over tillage system and experimentation year.

\section{Results}

\subsection{Bredlow Corner Trials}

Significant differences $(a=0.05)$ were observed for herbicide treatments on Italian ryegrass control throughout the growing period each year. Metribuzin $\mathrm{fb}$ pinoxaden provided better Italian ryegrass control (88.5\% in 2006-2007; 87.7\% in 2007-2008 and 83.5\% in 2008-2009) compared to other herbicide 
treatments at all evaluation times (Figure 1a-c). The control of Italian ryegrass declined for herbicide treatments consisting of a single active ingredient, except the mixtures containing metribuzin, toward the end the growing season (Figure 1a-c). Single applications of either pinoxaden or mesosulfuron controlled Italian ryegrass less than two applications of metribuzin, or other herbicide treatments, approximately 16 WAE (Figure 1a-c). The control of diclofop-resistant Italian ryegrass was significantly ( $a=0.05$ ) less with a single pinoxaden application, which was $41 \%$ to $68 \%$ between $n 2006$ and 2009 . Control of diclofop-resistant Italian ryegrass with pinoxaden alone declined with time from $78 \%$ to $55 \%, 80 \%$ to $68 \%$ and $65 \%$ to $41 \%$ for the years $2006-2007,2007-2008$ and $2008-2009$, respectively (Figure 1a-c). Metribuzin followed by mesosulfuron was the only treatment that maintained control of diclofop-resistant Italian ryegrass at a satisfactory level (87-88\%) at all evaluation times.

The effectiveness of herbicide treatments was reflected on wheat grain yield as plots that received only a single pinoxaden application produced the lowest wheat yield, averaged across the years and tillage systems, equal to $1505 \mathrm{~kg} \mathrm{ha}^{-1}$ (Figure 2) compared to the other treatments. The plot treated with metribuzin $\mathrm{fb}$ mesosulfuron yielded highest $(2825 \mathrm{~kg} / \mathrm{ha})$. A single application of mesosulfuron resulted in $30 \%$ more grain yield $(2134 \mathrm{~kg} / \mathrm{ha}$ ) compared to a single application of pinoxaden.

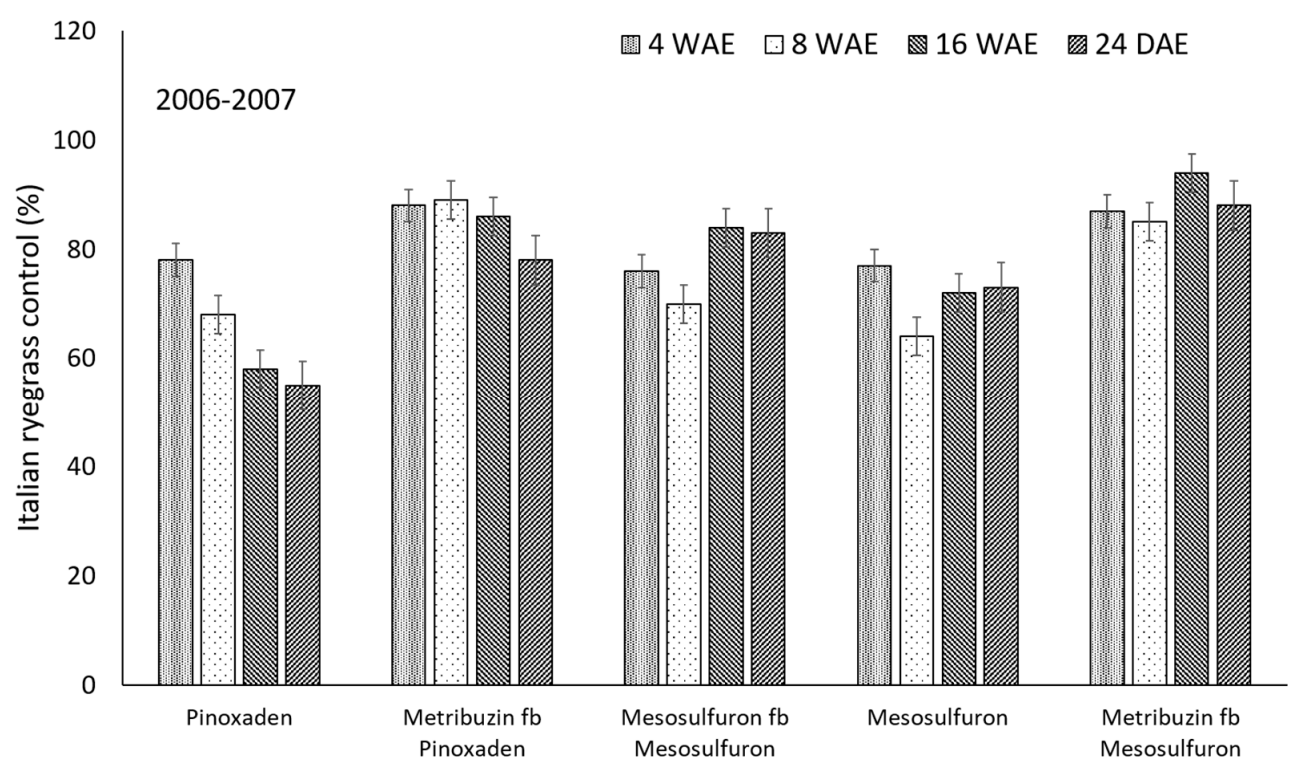

(a)

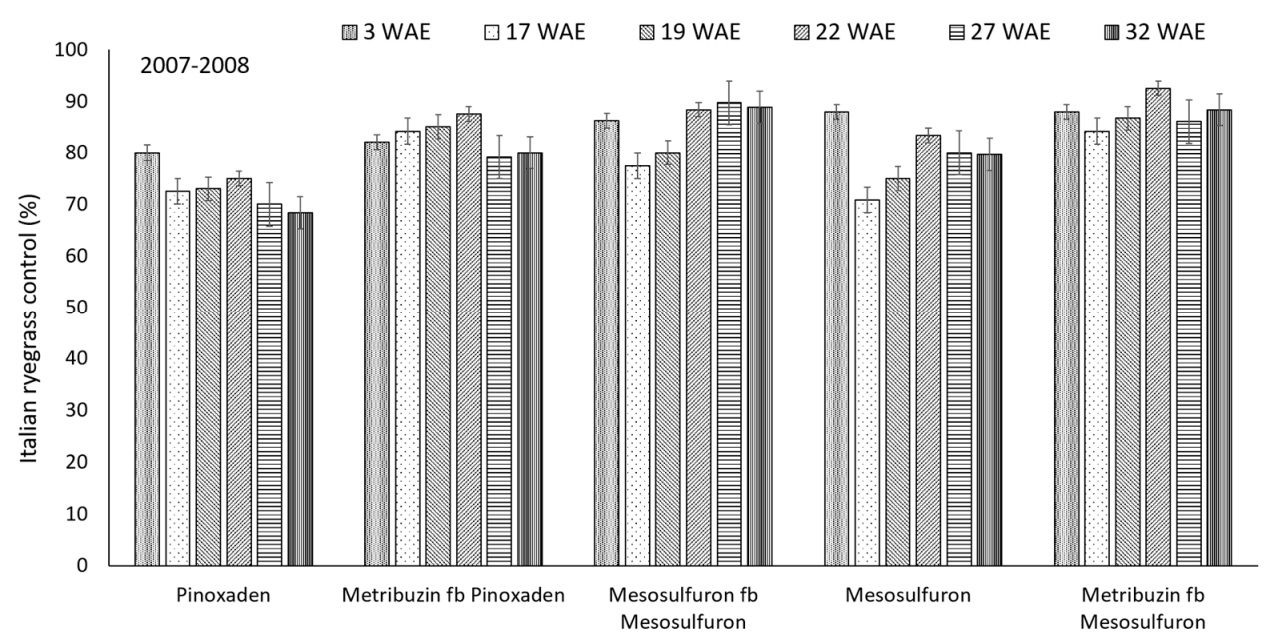

(b)

Figure 1. Cont. 


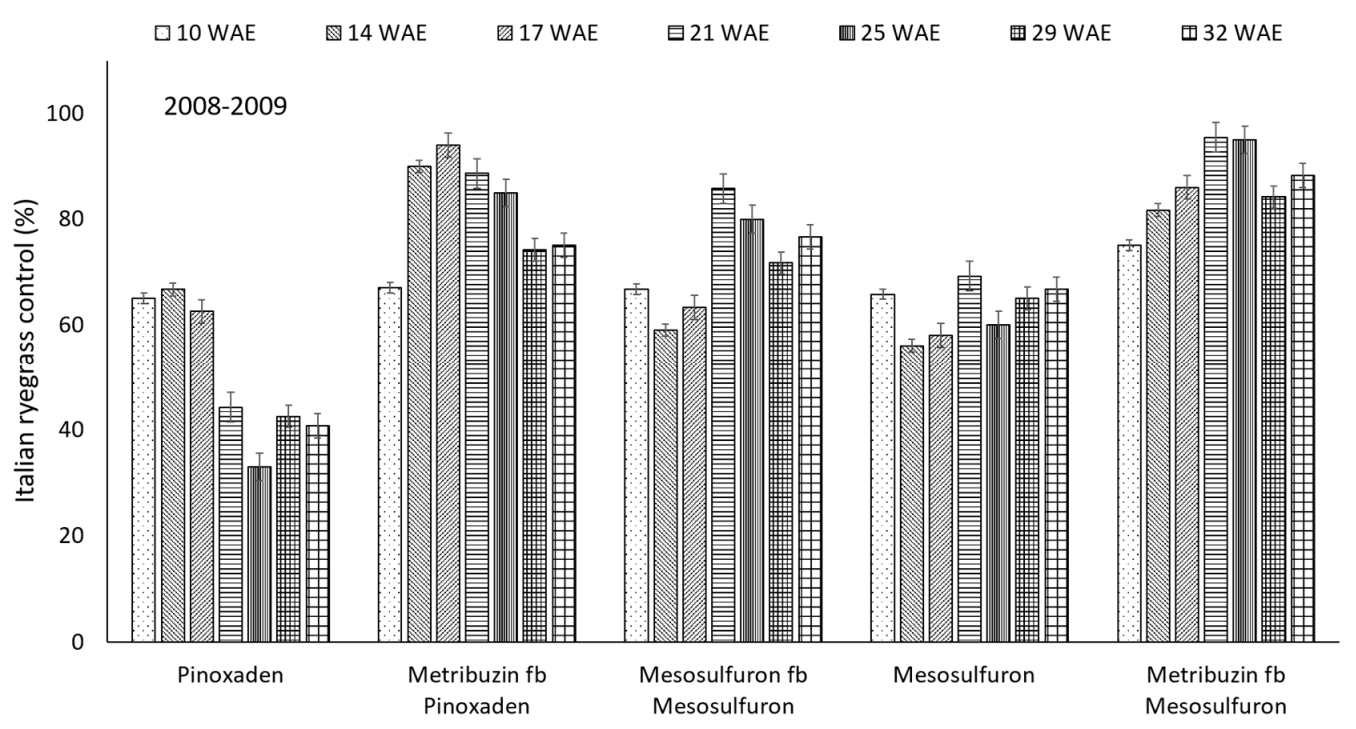

(c)

Figure 1. (a) Effects of herbicide program on percentage Italian ryegrass control in 2006-2007 experimental period. Vertical bars represent LSD at 5\% significance level (LSD for 4, 8, 16 and 24 $\mathrm{WAE}=5,9,9,15$ respectively); (b) Effects of herbicide program on percentage Italian ryegrass control in 2007-2008 experimental period. Vertical bars represent Least Significant Difference (LSD) at 5\% significance level (LSD for 3, 17, 19, 22, 27 and 32 WAE $=3$, 5, 6, 3, 9, 8 respectively); (c) Effects of herbicide program on percentage Italian ryegrass control in 2008-2009 experimental period. Vertical bars represent LSD at 5\% significance level (LSD for 10, 14, 17, 21, 25, 29 and 32 WAE = 2, 3, 5, 5, 5, 6,6 respectively). LSD $=$ Least Significant Diffrence, WAE $=$ Weeks after emergence, DAE $=$ Days after emergence.

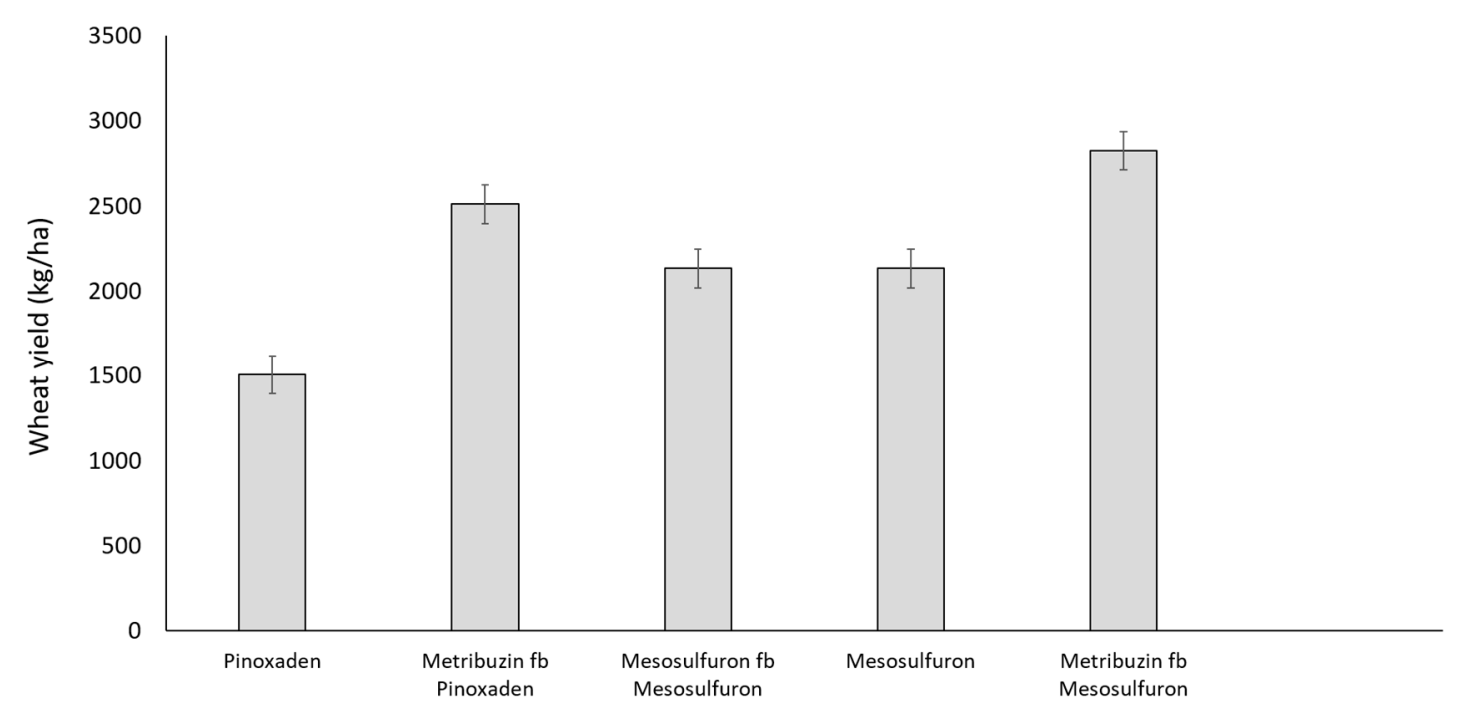

Figure 2. Effects of herbicide program on grain yield at Bredlow corner averaged across experimentation years and tillage systems. Vertical bars represent Least Significant Difference (LSD) at $5 \%$ significance level (LSD = 225.7).

\subsection{Fayetteville Trials}

The percentage control of diclofop-resistant Italian ryegrass by the single application of pinoxaden was the lowest amongst the other herbicide programs evaluated. More specifically, the control of Italian 
ryegrass 4 WAE was 75\% in 2006-2007 (Figure 3a) and the lowest was 39\% in 2007-2008 (Figure 3b). This activity declined with time in both years.

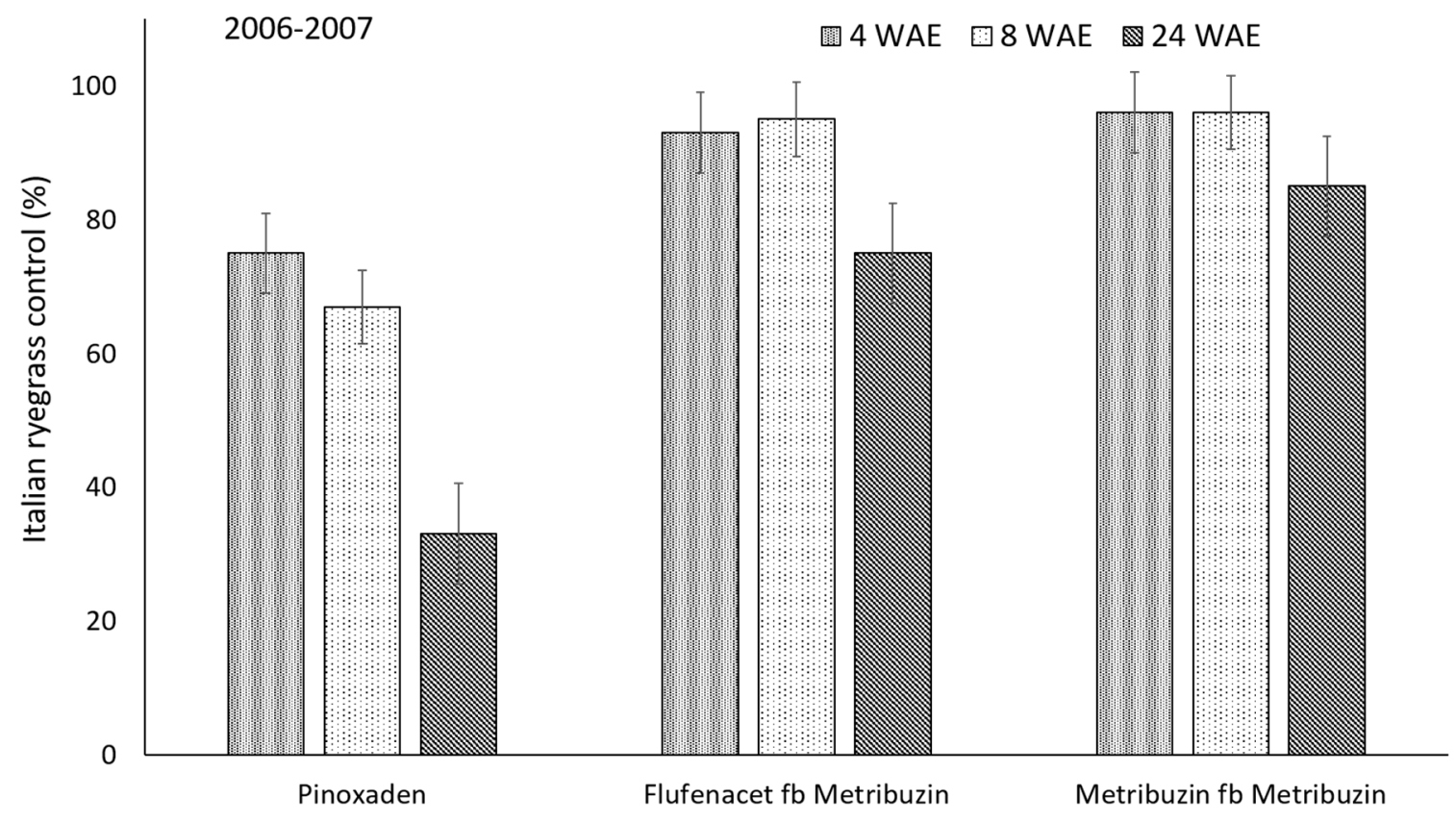

(a)

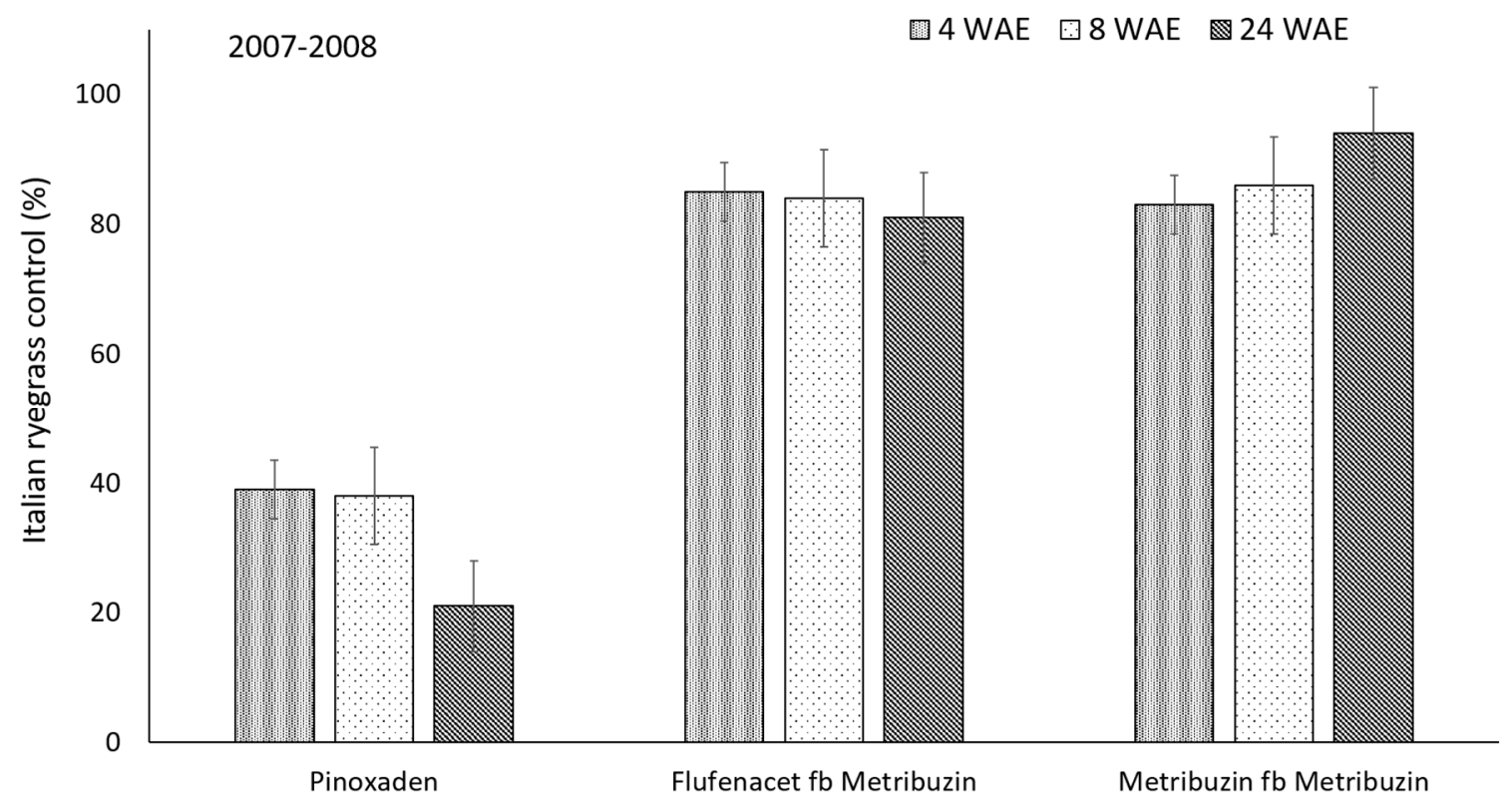

(b)

Figure 3. (a) Effects of herbicide programs on percentage Italian ryegrass control at Fayetteville 2006-2007 trials. Vertical bars represent LSD at 5\% significance level (LSD for 4, 8, and 24 WAE $=11,10$, 18 respectively). (b) Effects of herbicide programs on percentage Italian ryegrass control at Fayetteville 2007-2008 trials. Vertical bars represent Least Significant Difference (LSD) at $\%$ significance level (LSD for 4, 8 and $24 \mathrm{WAE}=10,17$ and 16 respectively).

Flufenacet $\mathrm{fb}$ metribuzin controlled Italian ryegrass $93 \%$ four [4] WAE in 2006-2007, declining to $75 \%$ at 24 WAE (Figure 3a). On the contrary, the efficacy of this treatment remained at $81-85 \%$ throughout the entire 2007-2008 growing season. 
The sequential metribuzin application was the best treatment for diclofop-resistant Italian ryegrass control in the Fayetteville test. This treatment controlled Italian ryegrass $96 \%$ and $85 \%$ at 4 WAE and 24 WAE, respectively in 2006-2007. This treatment was also the most effective in 2007-2008 season with $94 \%$ control 24 WAE.

The lowest yield, among all herbicide treatments, was obtained when pinoxaden was applied alone (Table 4). This treatment produced similar yield as the weedy check, which produced plots $1506 \mathrm{~kg} / \mathrm{ha}$ ) in 2007-2008 period (Table 4). The plots treated with flufenacet fb metribuzin produced approximately $38 \%$ more grain yield compared to plots treated with pinoxaden alone (Table 4 ). The application of metribuzin fb metribuzin produced the highest grain yield in 2006-2007 and 2007-2008 cropping seasons with up to $5084 \mathrm{~kg} /$ ha yield (Table 4).

Table 4. Effects of herbicide program on grain yield $\left(\mathrm{kg} \mathrm{ha}^{-1}\right)$ at Fayetteville in 2006-2007 and 2007-2008 experimental periods. LSD $=$ Least Significant Difference.

\begin{tabular}{cccccc}
\hline Year & Control & Pinoxaden & $\begin{array}{c}\text { Flufenacet fb } \\
\text { Metribuzin }\end{array}$ & $\begin{array}{c}\text { Metribuzin fb } \\
\text { Metribuzin }\end{array}$ & LSD $(a=0.05)$ \\
\hline $2006-2007$ & 1067.1 & 2761.9 & 4707.7 & 5084.4 & 752.4 \\
$2007-2008$ & 1506.5 & 1945.9 & 3138.5 & 3766.2 & 564.3 \\
\hline
\end{tabular}

\subsection{Effects of Tillage on Italian Ryegrass Control}

Significant effect of tillage treatments was observed in 2007-2008 $(a=0.05)$ and 2008-2009 $(a=0.057)$ at Breadlow Corner. Italian ryegrass control was lower under tilled conditions than no-till regardless of herbicide program (Figure $4 a, b)$.

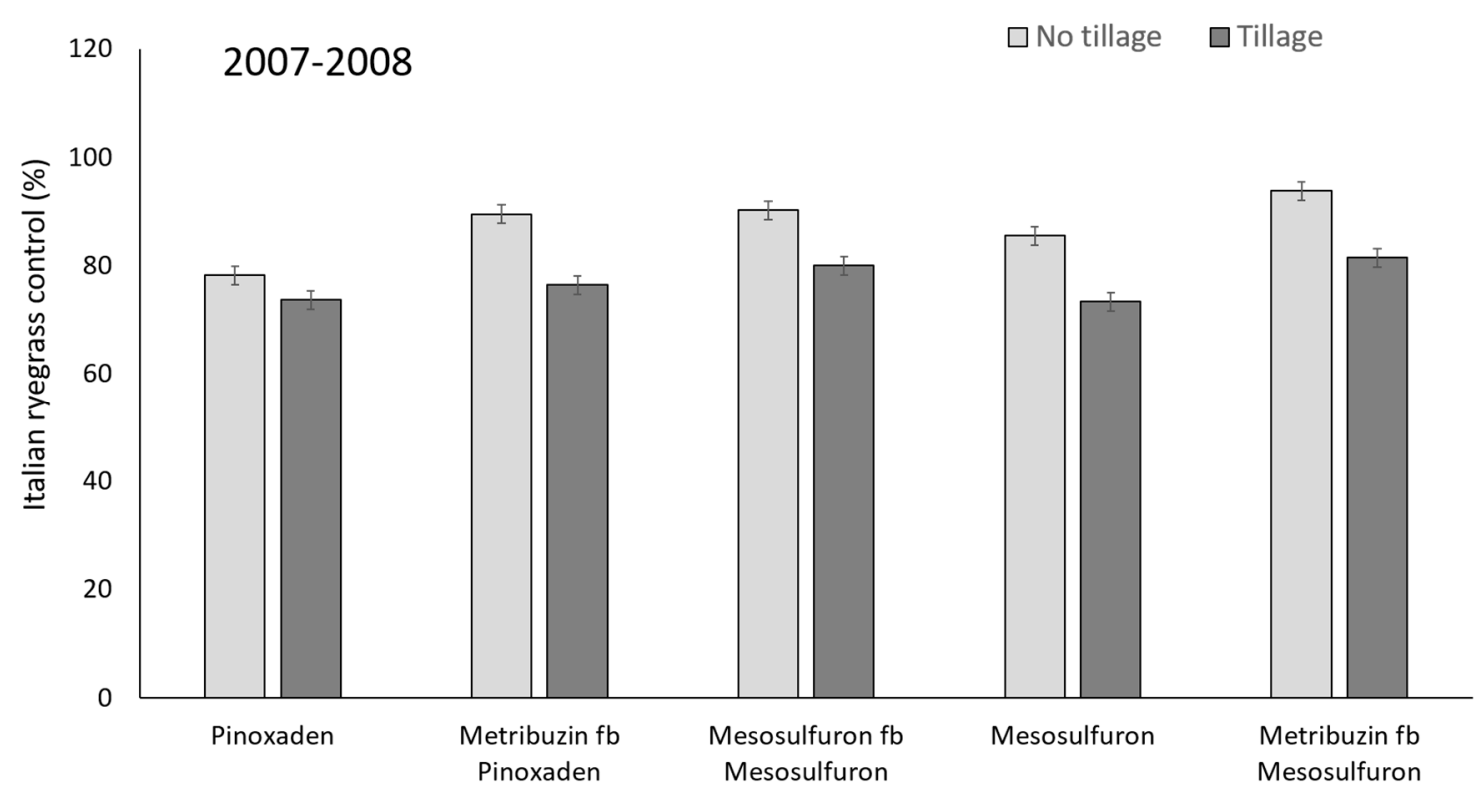

(a)

Figure 4. Cont . 


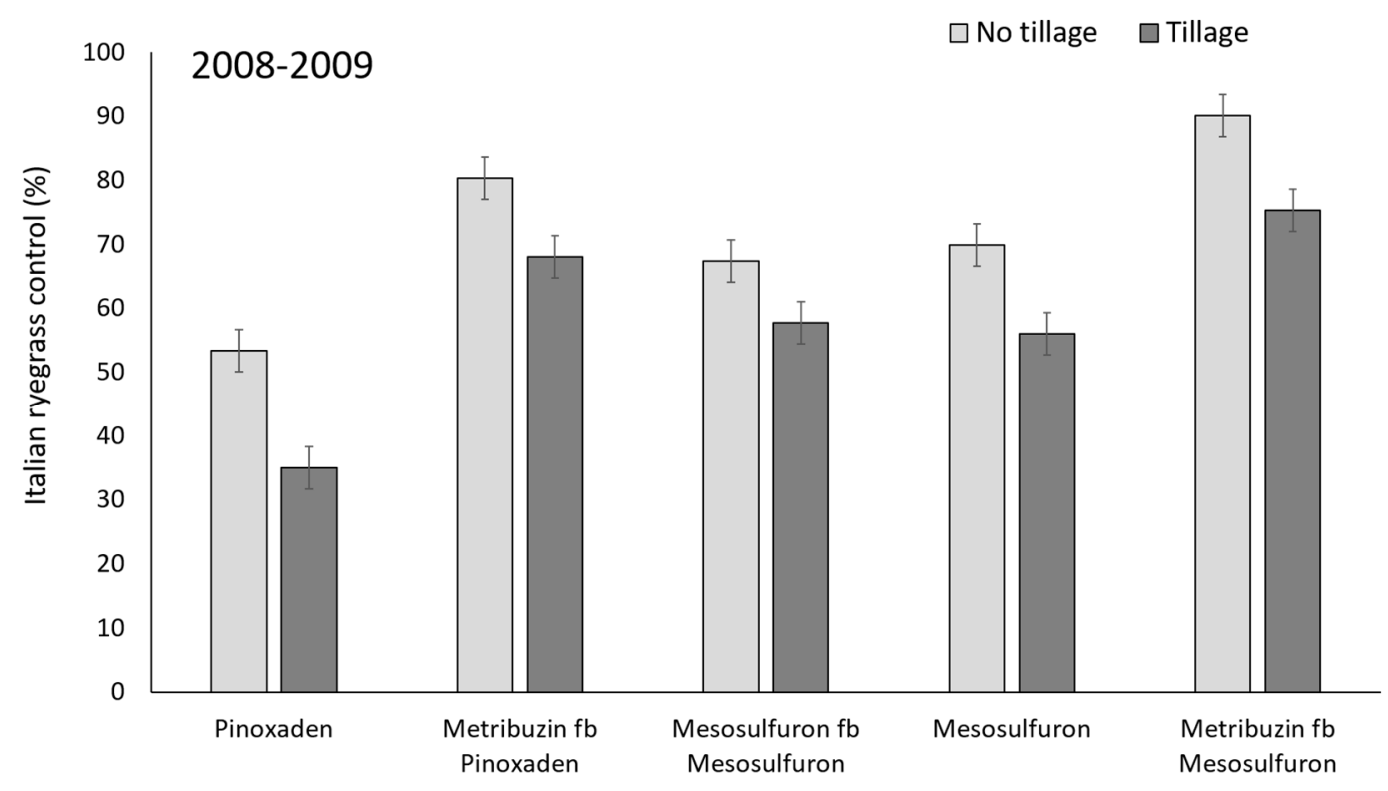

(b)

Figure 4. (a) Effects of herbicide program $\times$ tillage on percentage Italian ryegrass control in 2007-2008. Vertical bars represent Least Significant Difference (LSD) at 5\% significance level (LSD for tillage and no tillage treatments $=3$ ); (b) Effects of herbicide program $\times$ tillage on percentage Italian ryegrass control in 2008-2009. Vertical bars represent LSD at 5\% significance level (LSD for tillage and no tillage treatments $=9$ ).

\section{Discussion}

\subsection{Effects of Herbicide Treatment on Diclofop-Resistant Italian Ryegrass and Grain Yield}

Pinoxaden is an ACCase-inhibitor herbicide for selective grass weed control in wheat and barley (Hordeum vulgare L.) (Porter et al. [31]. Its phenylpyrazolin structure is different from the cyclohexanedione and aryloxyphenoypropanoate (AOPP) chemical structures, which allows it to bind at a different locus in the acetyl coenzyme-A carboxylase (ACCase) protein. Diclofop belongs to the AOPP chemical family of ACCase inhibitors; therefore, it was hypothesized that diclofop-resistant ryegrass is not cross-resistant to pinoxaden. A survey of Italian ryegrass in Arkansas by Kuk et al. [22] has shown $25 \%$ cross-resistance between diclofop and pinoxaden. The diclofop-resistant ryegrass population at the field sites fell into the $25 \%$ proportion, being cross-resistant to pinoxaden. The recommended rate of pinoxaden did not control 1- to 2-tiller Italian ryegrass and resulted in the lowest yields, not different from the weedy check. It has been recommended that appropriate management strategies should be developed for the control of diclofop (and other)-resistant Italian ryegrass which usually involve the use of alternative herbicide treatments as an immediate course of action [22]. Our research demonstrated that planting no-till wheat is an effective tool for reducing ryegrass population size, which improves the efficacy of herbicides.

The amount of yield loss incurred with insufficient ryegrass control demonstrates the importance of managing this weed. Cross-resistant populations, when treated with pinoxaden, can incur close to $50 \%$ yield loss. This highlights the importance also of resistance testing. Characterization of the resistance profile of field populations will allow the growers to plan an appropriate herbicide treatment. Pinoxaden is still effective on $75 \%$ of the diclofop-resistant populations. The grower just needs to know the nature of his ryegrass population.

The high competitive ability of ryegrass is due to its high tillering that chokes the wheat. Under heavy ryegrass infestation yield loss can be up to $92 \%$ (Hashem et al. [32]. According to these authors one Italian ryegrass plant among 100 winter wheat plants $/ \mathrm{m}^{2}$ caused $33 \%$ yield loss. 
Italian ryegrass populations in the southern United States have evolved cross- and multiple resistance to various herbicide classes including ACCase and ALS inhibitors, and even to glyphosate. There is evidence that enhanced herbicide metabolism is partially responsible for resistance to diclofop, pinoxaden, mesosulfuron, and pyroxsulam in some Italian ryegrass populations [33]. If this is true, it is possible that cross-resistance and multiple-resistance can ensue because of cross-reactivity of some detoxifying enzymes.

Due to the obligatory outcrossing reproductive nature of Italian ryegrass, plants exhibiting multiple resistance mechanisms could hybridize and produce offspring carrying new combination of resistance genes that may enable new resistant phenotypes [34]. Because of increasing resistance to ALS inhibitors, on top of resistance to ACCase inhibitors, the remaining herbicide options for Italian ryegrass control include pendimethalin and flufenacet plus metribuzin [33] and, recently, pyroxasulfone.

\subsection{Effects of Tillage $\times$ Herbicide Treatment on Italian Ryegrass Control}

In the past few years, there has been a growing trend towards reducing tillage in cropping systems to allow stubble retention, earlier planting and improved soil structure. However, the adoption of conservation tillage systems will change weed control practices [35]. No-tillage significantly reduced the ryegrass population size across years. In this case, the efficacy of herbicides would be improved because of better coverage per plant with respect to foliar herbicides and higher dosage per plant with respect to soil-applied herbicides. Further, tillage systems exert a significant influence on the vertical distribution of weed seeds in the soil seed bank. As stated by Korres et al. [36] the persistence of the soil seedbank depends on a wide range of interacting biotic and abiotic factors including burial depth. Under tilled conditions, a large proportion of the seedbank is buried beyond the emergence zone and would lay dormant. New deposits of seeds each year increases the seedbank size. Therefore, tillage practices could serve as a conservation medium for the seeds of Italian ryegrass. Under no-tillage, the deeply buried seeds are not excavated and will eventually lose viability with time. Those in the emergence zone will be controlled by herbicides. New seeds deposited on the soil surface either germinate and are controlled, or are subjected to predation or other avenues of loses. Thus, no-tillage help reduce ryegrass population.

\section{Conclusions}

In conclusion, the diclofop-resistant Italian ryegrass at the study locations was cross-resistant to pinoxaden. A single pinoxaden application did not control this population. The best herbicide treatments for diclofop-resistant ryegrass are split application of metribuzin, a premix of saflufenacet and metribuzin, or saflufenacet followed by metribuzin. No-tillage reduces the ryegrass population size of ryegrass more than conventional tillage and enhances the efficacy of wheat herbicides.

Author Contributions: Investigation and Methodology, T.B.; Formal analysis, N.E.K., T.B.; Writing original draft: N.E.K., T.B., R.R.H.; Writing review and Editing: N.R.B., N.E.K., T.-M.P.T.

Funding: This research received no external funding

Conflicts of Interest: The authors declare no conflict of interest.

\section{References}

1. Everman, W.; Jordan, D. Small grain weed control. In 2011-2012 Small Grain Production Guide; Weisz, R., Ed.; AG-580; North Carolina Cooperative Extension: Raleigh, NC, USA, 2011; pp. 71-79.

2. Webster, T.M. Weed survey-Southern states. In Proceedings of the 53nd Annual Meeting Southern Weed Science Society, Y2K: The Challenge of Change, Tulsa, OK, USA, 24-26 January 2000; Reynolds, D.B., Ed.; Southern Weed Science Society: Tulsa, OK, USA, 2000; pp. 247-274.

3. Worthington, M.L.; Reberg-Horton, S.C.; Jordan, D.; Murphy, J.P. A comparison of methods for evaluating the suppressive ability of winter wheat cultivars against Italian ryegrass (Lolium perenne). Weed Sci. 2013, 61, 491-499. [CrossRef] 
4. Appleby, A.P.; Olson, P.D.; Colbert, D.R. Winter-wheat yield reduction from interference by Italian ryegrass. J. Agron. 1976, 68, 463-466. [CrossRef]

5. Bararpour, M.T.; Oliver, L.R. Comparison of wheat herbicides for control of Arkansas diclofop-resistant Italian ryegrass. In Proceedings of the Arkansas Crop Protection Association, Fayetteville, AR, USA, 26-27 November 2007; Volume 11.

6. Bararpour, M.T.; Norsworthy, J.K.; Burgos, N.R.; Korres, N.E.; Gbur, E.E. Identification and biological characteristics of ryegrass (Lolium spp.) accessions in Arkansas. Weed Sci. 2017, 65, 350-360. [CrossRef]

7. Bond, J.A.; Stephenson, D.O., IV; Barnes, J.W.; Bararpour, M.T.; Oliver, L.R. Diclofop-resistant Italian ryegrass (Lolium multiflorum) control in imidazolinone-tolerant wheat. Weed Technol. 2005, 19, 437-442. [CrossRef]

8. Crooks, H.L.; York, A.C.; Jordan, D.L. Wheat (Triticum aestivum) tolerance and Italian ryegrass (Lolium multiflorum) control by AE F130060 plus AE F115008 mixed with other herbicides. Weed Technol. 2003, 17, 881-889. [CrossRef]

9. Griffin, J.L. Ryegrass (Lolium multiflorum) control in winter wheat (Triticum aestivum). Weed Sci. 1986, 34, 98-100.

10. Justice, G.G.; Peeper, T.F.; Solie, J.B.; Epplin, F.M. Net returns from Italian ryegrass (Lolium multiflorum) control in winter wheat (Triticum aestivum). Weed Technol. 1994, 8, 317-323. [CrossRef]

11. Khodayari, K.; Frans, R.E.; Collins, F.C. Diclofop-a selective herbicide for Italian ryegrass (Lolium multiflorum) control in winter wheat (Triticum aestivum). Weed Sci. 1983, 31, 436-438.

12. Betts, K.J.; Ehlke, N.J.; Wyse, D.L.; Gronwald, J.W.; Somers, D.A. Mechanism of inheritance of diclofop resistance in Italian ryegrass (Lolium multiflorum). Weed Sci. 1992, 40, 184-189. [CrossRef]

13. Stranger, C.E.; Appleby, A.P. Italian ryegrass (Lolium multiflorum) accessions tolerant to diclofop. Weed Sci. 1989, 37, 350-352.

14. Grey, T.L.; Bridges, D.C. Alternatives to diclofop for the control of Italian ryegrass (Loliu multiflorum) in winter wheat (Triticum aestivum). Weed Technol. 2003, 17, 219-223. [CrossRef]

15. Perez, A.; Kogan, M. Glyphosate-resistant Lolium multiflorum in Chilean orchards. Weed Res. 2003, 43, 12-19. [CrossRef]

16. Perez-Jones, A.; Park, K.; Colquhoun, J.; Mallory-Smith, C.; Shaner, D. Identification of glyphosate-resistant Italian ryegrass (Lolium multiflorum) in Oregon. Weed Sci. 2005, 53, 775-779. [CrossRef]

17. Bond, J.A.; Eubank, T.W.; Bond, R.C.; Golden, B.R.; Edwards, H.M. Glyphosate-resistant Italian ryegrass (Lolium perenne ssp. multiflorum) control with fall-applied residual herbicides. Weed Technol. 2014, 28, 361-370.

18. Nandula, V.K.; Poston, D.H.; Eubank, T.W.; Koger, C.H.; Reddy, K.N. Differential response to glyphosate in Italian ryegrass (Lolium multiflorum) populations from Mississippi. Weed Technol. 2007, 21, 477-482. [CrossRef]

19. Bond, R.C.; Bond, J.A.; Eubank, T.W.; Nandula, V.K. Clethodim-based programs for managing glyphosate-resistant Italian ryegrass. Proc. South. Weed Sci. Soc. 2011, 64, 17.

20. Heap, I. Herbicide Resistant Weeds. Available online: http://www.weedscience.org (accessed on 8 November 2017).

21. Carpenter, J.; Gianessi, L. Herbicide tolerant soybeans: Why growers are adopting Roundup Ready varieties. AgBio Forum 1999, 2, 65-72.

22. Kuk, Y.I.; Burgos, N.R.; Scott, R.C. Resistance Profile of Diclofop-Resistant Italian Ryegrass (Lolium multiflorum) to ACCase- and ALS-Inhibiting Herbicides in Arkansas, USA. Weed Sci. 2007, 56, 491-499.

23. Taylor, J.M.; Coats, G.E. Identification of sulfometuron-resistant Italian ryegrass (Lolium multiflorum) selections. Weed Technol. 1996, 10, 943-946. [CrossRef]

24. Cerdeira, A.L.; Duke, S.O. The current status and environmental impacts of glyphosate-resistant crops: A review. J. Environ. Qual. 2006, 35, 1633-1658. [CrossRef] [PubMed]

25. Service, R.F. Glyphosate-The conservationist's friend? Science 2007, 316, 1116-1117. [CrossRef] [PubMed]

26. Vencill, W.K.; Banks, P.A. Effects of tillage systems and weed management on weed populations in grain sorghum (Sorghum bicolor). Weed Sci. 1994, 42, 541-547.

27. Kegode, G.O.; Forcella, F.; Clay, S. Influence of crop rotation, tillage, and management inputs on weed seed production. Weed Sci. 1999, 47, 175-183.

28. Locke, M.A.; Reddy, K.N. Zablotowicz RM Weed management in conservation crop production systems. Weed Biol. Manag. 2002, 2, 123-132. [CrossRef] 
29. Anonymous. Axial XL Herbicide Label. Available online: http://www.cdms.net/ldat/ld9M9000.pdf (accessed on 8 March 2018).

30. Zadoks, J.C.; Chang, T.T.; Konzak, C.F. A decimal code for the growth stages of cereals. Weed Res. 1974, 14, 415-421. [CrossRef]

31. Porter, D.J.; Kopec, M.; Hofer, U. Pinoxaden-A new selective postemergence graminicide for wheat and barley. Weed Sci. Soc. Am. 2005, 45, 95.

32. Hashem, A.; Radosevich, S.R.; Roush, M.L. Effect of proximity factors on competition between winter wheat (Triticum aestivum) and Italian ryegrass (Lolium multiflorum). Weed Sci. 1998, 46, 181-190.

33. Salas, R.A.; Burgos, N.R.; Mauromoustakos, A.; Lassiter, R.B.; Scott, R.C.; Alcober, E.A. Resistance to ACCase and ALS inhibitors in Lolium perenne ssp. multiflorum in the United States. J. Crop Weed 2013, 9, 168-183.

34. Scarabel, L.; Panozzo, S.; Varotto, S.; Sattin, M. Allelic variation of the ACCase gene and response to ACCase-inhibiting herbicides in pinoxaden-resistant Lolium spp. Pest Manag. Sci. 2011, 67, 932-941. [CrossRef] [PubMed]

35. Chauhan, B.S.; Gill, G.S.; Preston, C. Tillage system effects on weed ecology, herbicide activity and persistence: A review. Aust. J. Exp. Agric. 2006, 46, 1557-1570. [CrossRef]

36. Korres, N.E.; Norsworthy, J.K.; Young, B.G.; Reynolds, D.B.; Johnson, W.G.; Conley, S.P.; Smeda, R.J.; Mueller, T.C.; Spaunhorst, D.J.; Gage, K.; et al. Seedbank persistence of Palmer amaranth (Amaranthus palmeri) and waterhemp (Amaranthus tuberculatus) across diverse geographical regions in the United States. Weed Sci. 2018. [CrossRef]

(C) 2018 by the authors. Licensee MDPI, Basel, Switzerland. This article is an open access article distributed under the terms and conditions of the Creative Commons Attribution (CC BY) license (http:/ / creativecommons.org/licenses/by/4.0/). 